\title{
Valued Added Tax (VAT) Impact on Economic and Societal Well-Beings (Pre-and Post COVID19): A Perception Study From Saudi Arabia
}

\author{
Siti Norwahida Shukeri ${ }^{1} \&$ Faisal D Alfordy ${ }^{1}$ \\ ${ }^{1}$ Department of Accounting, College of Business Administration, University of Hail, Hail, Kingdom of Saudi Arabia \\ Correspondence: Siti Norwahida Shukeri, Department of Accounting, College of Business Administration, \\ University of Hail, Hail, Kingdom of Saudi Arabia.
}

Received: July 13, 2020

Accepted: September 1, 2020

Online Published: December 24, 2020

doi:10.5430/ijfr.v12n1p92

URL: https://doi.org/10.5430/ijfr.v12n1p92

\begin{abstract}
The Kingdom of Saudi Arabia (KSA) has realized that merely relying on oil reserves, as the main income source will stop the country from achieving sustainable economic growth due to the instability of world oil market prices and its uncertainties. Hence, the first Value Added Tax (VAT) has been introduced in KSA in 2018 following to the urge by International Monetary Fund (IMF). However, VAT implementation in the Kingdom is not free from criticisms since its citizens, particularly younger generation, have been used to tax-free livings. In addition, the global health pandemic of COVID19 has hit major economies worldwide. In correspondence, KSA has decided to increase its VAT rate to $15 \%$ from $5 \%$ by the $1^{\text {st }}$ of July 2020 , which may suggest a different pattern of consumption behaviour since the rate has been drastically increased. Therefore, this study aims to examine the perception of Saudi younger generation on the acceptance of VAT based on five categorical factors underlying Saudi younger generation's level of acceptance or rejection of VAT, namely; tax system effectiveness (TSE), income generation sources (IGS), income inequality (II), system knowledge (SK) and global practice (GP). The study also is set to examine the impact of VAT on Saudi younger generation's consumption behaviour. Using a sample of 460 respondents, the findings reveal that most of the respondents (89.6\%) are aware of VAT implementation. However, the negative perceptions found from the analysis shows that VAT is not an efficient tax system to be implemented (average TSE $=45.6 \%$ less favourable) as the VAT system does not provide income inequality among citizens (average II $=45.3$ percent less favourable). Moreover, the results also show that VAT implementation does not affect the consumption behaviour, suggesting that Saudi younger generation still spends regardless of VAT. Limited studies among the GCC academics on VAT has motivated this research to be among the first attempt to document such impact and to consider it in lights of new legislative changes due to COVID-19. Hence, this study is both timely and relevant to provide new understandings to responsible authorities regarding its VAT system, its acceptance and impacts on consumption behaviour in lights of COVID-19.
\end{abstract}

Keywords: value add tax, taxation, income inequality, tax social justice

\section{Introduction}

Taxation is defined as a social cost that societal members must bear in order to enable governments to fund and maintain its infrastructures and public services (Zanganeh, Sheikhi \& Abdollahi, 2018). In addition, taxation is a way of generating revenues from individuals and companies by governments for its economic and social developments in order to reduce the gap between poor and rich section of societies. Therefore, it is quite a common practice for governments to resort to taxation as a source of generating internal income when local economies are faced with challenges. In fact, the implementation of VAT in the GCC countries including Saudi Arabia has been coinciding with the sharp decrease in oil prices, and is expected to have a significant function in re-shaping the direction of economic and social systems.

In the year 2016, the Saudi government launched its Vision 2030 with an aim to promote less dependency on oil \& gas reserves and called upon its regulatory bodies to diversify its economic resources. In January 2018, the Kingdom of Saudi Arabia has joined other GCC countries in implementing VAT (General Authority of Zakat and Tax(GAZT), 2018). In July 2018, the Saudi General Authority of Zakat and Tax released its final modified draft of its VAT laws 
and regulations highlighting that all imports and supplies of goods and services in the Kingdom of Saudi Arabia (KSA) will be subjected to VAT at a standard rate of 5\%, complying fully with the GCC's VAT Framework Agreement (Deloitte, 2017).

Despite of being used to tax-free living for many years, Saudi regulators believe that the imposing of VAT would provide positive contributions, and such contributions is expected to be significant since it will be levied on all goods and services (with a few exemptions). (Note 1) Saudi Arabia level of imported merchandises' value is about SAR660 billion as of the year end 2018 (Saudi General of Authority Statistics, 2019). In line with the early prediction, Saudi Arabia has generated SAR113 billions of VAT revenues during the first year of implementation, 2018, and SAR132 billions in the second year, in 2019, which highlights a fundamental shift in the Kingdom's revenue generating mechanisms (GAZT, 2019).

VAT is deemed according to vision 2030 as a progressive step in reforming Saudi economy and making it less reliance on oil and gas. In addition, the implementation of VAT is expected to enhance the market efficiency, and transparency. However, as VAT becoming a popular issue discussed by all Saudi citizens on a daily basis, some Saudi citizens are still unaware or confused about VAT as a tax system regardless of the Saudi governments' many awareness programs. In addition, the Saudi government's introducing of VAT is not free from criticism as tax is assumed a burdensome and provides income inequalities among nationals. The critics have driven VAT to be claimed as one of the wrong income generating policy by the government and is highly rejected by most people particularly younger generations.

Economically, VAT is defined as a consumption tax and for very consumption made, the tax is charged indirectly leading to high spending costs. There are endless debates whether VAT causes higher spending's or vice versa, whether VAT is only one sided-win to governments or whether VAT could improve the overall economical system of such country. Therefore, the Saudi government undertook a series of policy measures to reduce the overall impacts of VAT on its citizens. Among the initiatives undertaken, there was a proposed increase of salaries for all Saudi nationals in the civil, public, and military services by SAR1, 000 in 2018. In addition, all private sectors' organizations were encouraged by the Saudi governments to follow suits. In addition, the salary increase was accompanied with the establishment of the National Account Agency providing monthly subsidies for all citizens in the public and private sectors with salaries less than SAR20, 000 (Mogielnicki, 2019).

Regardless of all Saudi government's attempts to lessen the assumed impact of VAT on its citizens, it is necessary to examine the perception of Saudi younger generation on their awareness of VAT, its acceptance, and its impact on their consuming behaviours since they are viewed to play an integral part of the Saudi government's plan to transform its economy (McKinsey, 2015). In addition, this study is both timely and critical since Saudi Arabia has just initiated the increase of its VAT standard rate from 5\% to $15 \%$ due to the COVID-19 virus effective on the $1^{\text {st }}$ of July 2020. This increase was proposed in parallel with taken out the salary increase of SAR1,000, which was initiated two years ago. In addition, Saudi Arabia total revenues figure in the first quarter was down by $22 \%$ from the same period last year; oil revenues fell by $24 \%$ in Q1 2020 to SAR128.771 billions, and VAT revenues fell by 17\% during the first quarter of this year to SAR35.6 billions (GAZT, 2020). Therefore, the objectives of this case study are two-folds: 1) To examine the acceptance of younger generation of VAT using five categorical factors namely; tax system effectiveness (TSE), income generation sources (IGS), income inequality (II), system knowledge (SK) and global practice (GP); and, 2) To examine changes in younger generation consuming behaviors due to the implantations of VAT.

In addition, limited studies among the GCC academics and economists on VAT have motivated this research paper to be among the first research attempt to document such impact and to consider it in lights of new legislative changes due to COVID-19. Recent impacts of COVID-19 have led the Kingdom of Saudi Arabia to cut its government expenditures and increase its VAT rate to 15\%. It is also predicted that Saudi younger generation's consumption behaviour will also be affected upon the new revise rate of VAT. Hence, to fill in the gap found in the prior literatures, this study seeks to provide evidences with regard to VAT implementations, acceptance, and impact on consumption behaviour in a GCC country such as Saudi Arabia in lights of COVID-19.

The remainder of the paper is structured as follows. Section (2) discusses the literature review, presenting the conceptual framework of the study. Section (3) presents the research methodology employed. Section (4) provides a discussion of the analysis. And, Section (5) concludes the study, provides some potential research venues, suggestions, and highlights the limitations of this current research undertaking. 


\section{Literature Review}

Taxation in the GCC countries should ne be viewed as new phenomena as countries such as UAE, Kuwait and Saudi Arabia have adopted a few taxation forms since early 1980s. For instance, Kuwait and Saudi Arabia have implemented various tax policies such as corporate tax and income tax for expatriates since 1955 to 1975 . However, in 1975, Saudi Arabia suspended its income tax for expatriates. This is due to the discovered new scale of its oil revenues and increased demands for recruiting large numbers of foreign workers to aid in boosting the economy. Nevertheless, in 1988, Saudi Arabia has reintroduced again its income tax for expatriates to offset declining oil revenues and it has been existent ever after.

In the early 1990s, GCC countries considered the feasibility of introducing VAT as form of taxation as international organizations began publicly encouraging GCC countries to implement it as a form of taxation policy (Kawash, 1997). Nevertheless, the momentum for these international attempts faded away in despite of the United Nations Economic and Social Commission for West Asia's annual report of 1997 noting that, "significant scope [in the GCC states] to eliminate tariff exemptions, expand excise taxes and introduce a selective tax on luxury good" (Kawash,1997).

In 2002, the International Monetary Fund (IMF) has urged the GCC countries to start considering and focusing on non-oil revenues by improving their tax administrations and their tax systems (IMF, 2002). It was not until the year 2018 that some GCC countries such as UAE and Saudi Arabia have implementing VAT at a rate of 5\% effective from January 2018. Then, Bahrain followed up on the implementation, starting on January 2019 (Wadhwa, 2019). This has left only Oman, Kuwait and Qatar as the only GCC countries, which have not implemented VAT as a revenue generation stream as of yet. Table 1 shows the list of world regions implementing VAT, which is also known as Goods and Service Tax (GST) in different countries:

Table 1. List of regions implementing VAT

\begin{tabular}{|c|c|}
\hline Region & $\begin{array}{c}\text { No of } \\
\text { Countries } \\
\end{array}$ \\
\hline GCC & 3 \\
\hline ASIA & 21 \\
\hline ASEAN & 8 \\
\hline EUROPE & 53 \\
\hline OCEANLA & 7 \\
\hline AFRICA & 44 \\
\hline SOTH AMERICA & 11 \\
\hline CARIBBEAN, CENTRAL AMERICA AND NORTH AMERICA & 19 \\
\hline TOTAL & 166 \\
\hline
\end{tabular}

There is no doubt that VAT is among the most widely adopted form of taxation by most countries worldwide (Note 2); nevertheless, evidences supporting the efficiency of VAT as a taxation system are still ambiguous (Adhikari, 2020). Generally, taxation is defined as a social cost that members of such society must bear in order to provide returns and balanced facilities to societies (Zanganeh, Sheikhi \& Abdollahi, 2018). In addition, this form of revenue generating mechanism is claimed to be capable of reducing the gap between high and low-income earners in countries. However, recent evidence in Saudi Arabia provided by Omar, (2018) investigated the effect of VAT on income equality and does not find interesting findings to back up the VAT system in terms of promoting income equality

In searching for evidences whether VAT is an efficient tax system to promote income equality, Chan and Raml, (2018) studied the role of country governance and income equality by means of VAT implementation. They documented that VAT reduces income inequality provided that country governance is of good support with less bureaucracy, better accountability and stability. In addition, Metekohy (2015) studied the influence of VAT on income distribution in garment industry and found out that VAT is a burdensome, and does not promote equal 
income distributions. In different business sectors such as Small \& Medium Enterprises (SMEs), a study reported that VAT is found a burdensome to SME's operators as their profit margins are relatively low; hence, VAT may be a risky tax system for SME's to grow (Ramli et al., 2015).

Despite the unfavourable impact of VAT to businesses and income disparity, a study in Malaysia has provided that Goods and Services Tax (GST), also Known as VAT, has improved the corporate governance regime (Chandren et al., 2019). In the study, Chandren et al., (2019) showed that the board composition (board independent, CEO age and family CEO) increased the sales performance during GST and after GST implementation. Also, the findings revealed that boards' of directors are found to to exercise more accountability to further improve their firms' performances, particularly after GST implementations.

Moreover, VAT is also found to improve individual consumption behaviour as evidenced by Kamaruddin and Mustapha (2017). Their study showed that GST knowledge among the respondents are at good level and concluded that people consumption behaviour has improved due to the implementation of GST.

Most of the prior literatures have documented negative effect of VAT with the exception of Chandren et al., (2019). This kind of tax system is still ambiguous in terms of its efficiency and also its acceptance among the public as many seen it as burdensome and create financial difficulties. Hakim, Karia and Bujang (2017) also supported the claims by showing negative association between tax system and economic growths in developing countries.

\section{Research Methodology}

This study follows the framework of a single country case study that is exploratory in nature. The method of collecting data is quantitative in nature employing a set of questionnaires as the main instrument for data collection. The questionnaire was adopted from Shaari, Alib and Ismail (2015), with minor modifications to suit the Saudi tax laws.

In order to examine the perception of Saudi younger generation on their acceptance of VAT, and its impact on their consuming behaviours prior and post COVID19, the all-primary data were gathered via questionnaires distributed to a group of 460 undergraduate business students at the University of Hail, Kingdom of Saudi Arabia. The questionnaires were targeting the answers of respondents when the standard rate of VAT was at $5 \%$, and at the new revised rate of $15 \%$.

The questionnaires included (16) items. These items are divided into three sections. The first section pertains to younger generation VAT's acceptance and is designed based on five categorical variables, which are; tax system effectiveness (TSE), income generation sources (IGS), income inequality (II), system knowledge (SK) and global practice (GP). The second section of the questionnaire is designed to collect data on the impact of VAT on younger generation's consuming behaviour. In this section, there is a clear distinction made between the effect of VAT on consumption behaviour as the effect of Selection Taxation. The third section of the questionnaire is designed to collect demographical data on respondents such as years of study, business programs, background, and age, (Tables 2 and 3) show the research framework and its operational measure applied in the study.

Table 2. Research framework and operational measure regarding VAT acceptance

\section{Categorical Factors Operational Measure (Survey Design)}

VAT aims to make the tax system more efficient, comprehensive and transparent

Tax System Effectiveness (TSE)

VAT aims to make the accounting system more efficient, comprehensive and transparent

VAT will have a stronger effect than the selective tax that was imposed earlier

\begin{tabular}{ll}
\hline Income Generation Sources (IGS) & VAT will generate and increase revenue for the country \\
\hline \multirow{3}{*}{ Income Inequality (II) } & VAT will not burden people \\
\cline { 2 - 2 } & VAT protects the interests of low income earners. \\
\cline { 2 - 2 } & VAT will result in higher prices for goods and services \\
\hline System Knowledge (SK) & Do not understand how VAT would be implemented \\
\hline Global Practice (GP) & $\begin{array}{l}\text { VAT is the best tax system adopted by many countries } \\
\text { around the world }\end{array}$ \\
\hline
\end{tabular}


Table 3. Research framework \& operational measure regarding impact of VAT on consumers' behaviour

\begin{tabular}{cl}
\hline Impact of VAT & \multicolumn{1}{c}{ Item } \\
\hline Behavioural Consumption & $\begin{array}{l}\text { VAT has positive effects on consumers' behaviour } \\
\text { Selective taxation has positive effects on consumers' } \\
\text { behaviour }\end{array}$ \\
\cline { 2 - 2 } & $\begin{array}{l}\text { Selective taxation on petro encourages students to share } \\
\text { a ride to come to the university }\end{array}$ \\
\hline
\end{tabular}

The sample size is inclusive of 460 undergraduate business students classified in terms of their different years of study, business programs, background, and age. Moreover, selection of respondents was done randomly and data collected was analysed descriptively to obtain the frequency and percentage, and comparative analysis using the software of Statistical Package for Social Science (SPSS) version 21.0.

\section{Research Findings}

\subsection{Demographic Analysis}

Table 3 shows the analysis of demographic profile employed in the study. There are about $30.4 \%$ male respondents and $69.6 \%$ female respondents participated in the study. The sample size covers $45.8 \%$ of total population, which is 460 respondents out of 1,005 students at University of Hail, Saudi Arabia.

Table 4. The number of male and female students

\begin{tabular}{ccrc}
\hline Gender & Frequency & Percent & Cumulative Percent \\
\hline Male & 140 & 30.4 & 30.4 \\
\hline Female & 320 & 69.6 & 100.0 \\
\hline Total & $\mathbf{4 6 0}$ & \multicolumn{2}{c}{$\mathbf{1 0 0 . 0 0}$} \\
\hline
\end{tabular}

Table 4 shows respondent's level of study, which are categorized based on their years of study. The analysis shows that $37.6 \%$ are from Seniors Level (4 ${ }^{\text {th }}$ Year), $24.1 \%$ are from Junior Level (3 ${ }^{\text {rd }}$ Year), $19.8 \%$ are from Sophomore Level (Second Year) and 18.5\% are from Freshman Level (First Year). The analysis is followed by respondents' fields of studies: which consist of $20 \%$ from Bachelor of Accounting students, $19.3 \%$ from Bachelor of Economic and Finance students, and 60.7\% from Bachelor of Management and Management Information System students. Moreover, $40.2 \%$ of respondents are aged between 18-20 years old, $25.7 \%$ of respondents are aged between 21-23 years old, $29.5 \%$ of respondents are aged more than 23 years old, and $4.6 \%$ of respondents are aged less than 18 years old. The analysis also highlighted the marital status: $89.60 \%$ of respondents are singles and only $10.40 \%$ of the respondents are married.

Table 5. Demographic information

\begin{tabular}{llccc}
\hline Categorical & & Particular & Frequency & Percentage \\
\hline \multirow{3}{*}{ Gender } & Male & Female & 140 & 30.4 \\
\cline { 2 - 4 } & & 320 & 69.6 \\
\hline \multirow{4}{*}{ Year of Study } & Freshman & $\mathbf{4 6 0}$ & $\mathbf{1 0 0 . 0 0}$ \\
\cline { 2 - 4 } & Sophomore & 85 & 18.5 \\
\cline { 2 - 4 } & Junior & 91 & 19.8 \\
\cline { 2 - 4 } & Senior & 111 & 24.1 \\
\cline { 2 - 4 } & & 173 & 37.6 \\
\hline \multirow{3}{*}{ Area of Study } & Accounting & $\mathbf{4 6 0}$ & $\mathbf{1 0 0 . 0 0}$ \\
\cline { 2 - 4 } & Economic and Finance & 92 & 20.0 \\
\cline { 2 - 4 } & Management and Information system & 89 & 19.3 \\
\hline
\end{tabular}




\begin{tabular}{llcc}
\hline & & $\mathbf{4 6 0}$ & $\mathbf{1 0 0 . 0 0}$ \\
\hline \multirow{4}{*}{ Age } & Less than 18 years old & 21 & 4.6 \\
\cline { 2 - 4 } & Between 18 to 20 years old & 185 & 40.2 \\
\cline { 2 - 4 } & Between 21 to 23 years old & 118 & 25.7 \\
\cline { 2 - 4 } & More than 23 & 136 & 29.5 \\
\cline { 2 - 4 } & & $\mathbf{4 6 0}$ & $\mathbf{1 0 0 . 0 0}$ \\
\hline \multirow{3}{*}{ Marital Status } & Married & 48 & 10.4 \\
\cline { 2 - 4 } & Single & 412 & 89.6 \\
\cline { 2 - 4 } & & $\mathbf{4 6 0}$ & $\mathbf{1 0 0 . 0 0}$ \\
\hline
\end{tabular}

\subsection{Descriptive Analyses}

Table 5 shows that $85 \%$ of respondents were aware of the implementation of VAT at its inception since January 2018. It leaves only $15 \%$ of the respondents not being aware about VAT implementation, consistent with a recent study by Kamaruddin and Mustapha (2017). The respondents received the information and knowledge about VAT through social media $80 \%, 8.4 \%$ are received from peers, 5.8\% from $\mathrm{UOH}$ awareness programs, $3.8 \%$ from magazines and newspapers, and $2 \%$ know about VAT from other sources. As information technology has become a main medium of information spread, these findings are of no apparent significance regarding younger generation.

Table 6. Awareness on the implementation of VAT

\begin{tabular}{lccc}
\hline $\begin{array}{c}\text { Awareness on the Implementation of } \\
\text { VAT }\end{array}$ & Frequency & Percent & Cumulative Percent \\
\hline Yes & 391 & 85 & 85 \\
\hline No & 69 & 15 & 100 \\
\hline Total & $\mathbf{4 6 0}$ & $\mathbf{1 0 0 . 0 0}$ & $\mathbf{1 0 0 . 0 0}$ \\
\hline
\end{tabular}

Only 15\% of respondents who were not aware of VAT stated their reasons as follow: $7.2 \%$ were not interested to know about VAT, $5.4 \%$ believed that they were not affected directly, and $2.4 \%$ claimed to have no time to know about VAT as it provides irrelevant information to them.

\subsubsection{The Five Categorical Variables of VAT Acceptance}

To understand how VAT is being accepted by the public, the study highlighted five categorical factors that have been examined in some prior literatures. Table 6 shows the tabulation of VAT acceptance influencing factors and provides general percentage scores for each factor. The findings show that most of respondents perceived VAT as less efficient tax systems (TSE $=45.6 \%$ ), unable to promote equality of income distribution (II $=45.3 \%$ ), followed by less knowledge with regard to VAT system (SK $=42.4 \%)$. Respondents rated VAT as non-instrumental of income generation sources (IGS $=34.3 \%$ ). The finding is further illustrated in Figure 1.

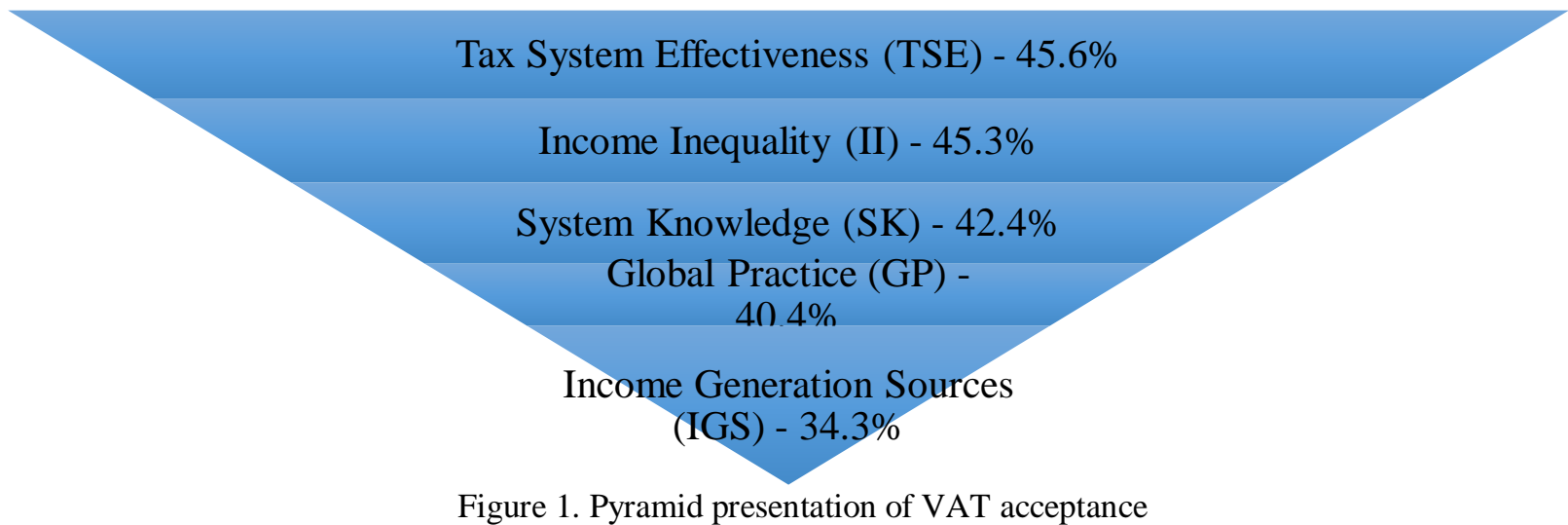

Figure 1. Pyramid presentation of VAT acceptance 
Table 7. Influencing factors of VAT acceptance

\begin{tabular}{lccccc}
\hline Influencing Factors & $\begin{array}{c}\text { Strongly } \\
\text { Disagree }\end{array}$ & Disagree & Neutral & Agree & $\begin{array}{l}\text { Strongly } \\
\text { agree }\end{array}$ \\
\hline Tax System Effectiveness (TSE) & 21.20 & 24.40 & 26.6 & 18.67 & 9.13 \\
\hline Income Generation Sources (IGS) & 15.50 & 18.80 & 24.60 & 22.50 & 18.60 \\
\hline Income Inequality (II) & 24.43 & 20.87 & 23.77 & 18.10 & 12.83 \\
\hline System Knowledge (SK) & 22.70 & 19.70 & 28.20 & 18.80 & 10.60 \\
\hline Global Practice (GP) & 21 & 19.40 & 30.10 & 18.10 & 11.40 \\
\hline
\end{tabular}

Table 8. (Un)Favourable VAT acceptance

\begin{tabular}{lcc}
\hline \multicolumn{1}{c}{ Influencing Factors } & $\begin{array}{c}\text { Favourable VAT } \\
\text { Acceptance }\end{array}$ & $\begin{array}{c}\text { Unfavourable VAT } \\
\text { Acceptance }\end{array}$ \\
\hline Tax System Effectiveness (TSE) & 27.80 & 45.6 \\
\hline Income Generation Sources (IGS) & 41.10 & 34.3 \\
\hline Income Inequality (II) & 30.93 & 45.3 \\
\hline System Knowledge (SK) & 29.40 & 42.4 \\
\hline Global Practice (GP) & 29.50 & 40.4 \\
\hline
\end{tabular}

The analysis provides evidences that VAT provides income inequality among the people in the Kingdom consistent with previous studies on VAT such as Chan \& Raml (2018) and Metekohy (2015). With the introduction of VAT, costs of consuming goods and services are expected to increase and lead to increases in living costs, and businesses' compliance cost (Hakim et al., 2017; Ramli et al., 2015). In addition, Unfavourable perception towards VAT implementation is also due to less knowledge regarding the Saudi VAT system, and how it redistributes the generated revenues on the well being of the Saudi society. Recent study by Kurma et al., (2019) shows consistent findings with this study where VAT introduction would be a failure due to less knowledge and government policy installed during the VAT implementation.

\subsubsection{Impact of Vat on Consuming Behaviour}

Due to the less favourable findings on the acceptance of VAT, this study aims to provide further analysis by examining the impact of VAT on behavioural consumption. Table 7 summarizes the findings.

Table 9. Impact of VAT on consumers behaviour

\begin{tabular}{|c|c|c|c|}
\hline $\begin{array}{l}\text { Impact of } \\
\text { VAT }\end{array}$ & Item & $\begin{array}{c}\text { Favourable VAT } \\
\text { Impact }\end{array}$ & $\begin{array}{c}\text { Unfavourable } \\
\text { VAT Impact }\end{array}$ \\
\hline \multirow{3}{*}{$\begin{array}{l}\text { Behavioural } \\
\text { Consumption }\end{array}$} & VAT has positive effects on consumers' behaviour & 31.30 & 43.70 \\
\hline & $\begin{array}{l}\text { Selective taxation has positive effects on consumers' } \\
\text { behaviour }\end{array}$ & 29.00 & 42.20 \\
\hline & $\begin{array}{l}\text { Selective taxation on petro encourages students to share } \\
\text { a ride to come to the university }\end{array}$ & 34.50 & 42.80 \\
\hline
\end{tabular}

Based on the analysis, it is shown that the implementation of VAT does not provide or improve the consumption behavior of respondents. Inconsistent with Kamaruddin and Mustapha (2017), the study does not provide any evidences that the imposing of VAT does not provide any impact on changing behavioral consumption. It concludes that regardless of having VAT imposed or not, younger generations' spending still unchanged. The findings conclude that behavioral consumption is not impacted by the introduction of VAT. Hence it supports the government new initiatives in increasing the VAT rate from $5 \%$ to $15 \%$ merely to improve government's national income due to COVID-19. 


\section{Conclusion}

Positive VAT collection of Saudi Arabia amounted to SAR45.6 billion has highlighted that VAT could be one of new revenue stream in the Kingdom. Despite of critics thrown at the policy maker, the public should be provided with an awareness program on the importance of VAT to promote the economic growth other than ultimately relying on oil-reserves income. The study investigates the underlying factors towards VAT acceptance among Saudi younger generation. Using five categorical factors, the study finds that VAT is not an efficient tax system to be implemented as it does not provide income inequality among the public. However, the findings managed to provide evidences that the awareness level regarding VAT is at good level supporting the motion that the respondents are aware of the government initiatives and implementation plans regarding VAT. To further emphasis the awareness and the importance of VAT and spread it out, the government can take the initiatives to provide awareness program especially among the younger generation. One mechanism is promoting VAT awareness through proper education channel such as incorporating it into the education syllabus such as Taxation Courses. It is importance to highlight that VAT is not as only burdensome income generation to the people, but it has more beneficial values that people could benefit from especially in times of crisis such as the current pandemic of COVID-19.

This study is of limitations for being a perception study rather than an empirical research study; hence, it limited the researchers from providing further inferential evidences regarding VAT acceptance, and impacts. Further research could enhance the value of research by investigating the VAT collections and its distribution channel to provide evidence on the positive impact of VAT. In conclusion, being the first study in the area of VAT, this paper is hopeful to provide preliminary evidences with regard to the VAT system introduction particularly in GCC countries, who have been living with tax free for many years.

\section{References}

Adhikari, B. (2020). Does a Value-Added Tax increase economic efficiency?. Economic Inquiry, 58(1), 496-517. https://doi.org/10.1111/ecin.12847

Al-Sasi, B. O. (2018). The potential positive impact of depreciation on the Value Added Tax (VAT) in the Saudi Arabian housing sector. Proceedings of the International Conference on Industrial Engineering and Operations Management, pp. 1485-1486.

Argaam. (2019). Budget Statement: Fiscal Year 2019. Ministry of Finance, Riyadh: Ministry of Finance. Retrieved 28 December 2019, from https://www.argaam.com/en/article/articledetail/id/1328587

Chan, S. G., \& Raml, Z. (2018). The role of country governance on value-added tax and inequality. E a M: Ekonomie a Management, 21(4), 79-93. https://doi.org/10.15240/tul/001/2018-4-006

Chandren, S., Ahmad, A. C., Ariff, A. H. M., \& Nadarajan, S. (2019). The impact of corporate governance on operating performance during goods \& services tax implementation in Malaysia. International Journal of Supply Chain Management, 8(3), 633-643.

Hakim, T. A., Karia, A. A., \& Bujang, I. (2016). Does goods and services tax stimulate economic growth? International evidence. Journal of Business and Retail Management Research, 10(3), 137-146.

International Monetary Fund. (2001). IMF Concludes 2001 Article IV Consultation with Saudi Arabia. Public Information Notice (PIN) No.01/119, 7 November 2001, Washington D.C. https://doi.org/10.5089/9781451804690.002

Kamaruddin, R., \& Mustapha, N. (2017). Malaysian spending patterns prior to Goods and Services Tax (GST) implementation. International Journal of Supply Chain Management, 6(2), 105-110.

Kasim, M. A., Hanafi, S. R. B. M., \& Suki, N. M. (2019). Relevance of technology acceptance model for the implementation of value added tax (VAT) in the United Arab Emirates (UAE): Evidence of distinctive behavioral connections. International Journal of Recent Technology and Engineering, 8(3), 6357-6365. https://doi.org/10.35940/ijrte.C5784.098319

Kumar, M., Barve, A., \& Yadav, D. K. (2019). Analysis of barriers in implementation of Goods and Service Tax (GST) in India using interpretive structural modelling (ISM) approach. Journal of Revenue and Pricing Management, 18(5), 355-366. https://doi.org/10.1057/s41272-019-00202-9

Merkx, M. (2019). VAT and Blockchain: Challenges and Opportunities Ahead. EC Tax Review, 28(2), 83-89.

Metekohy, S. (2015). The influence of value added tax (Vat) assessment on income distribution of consumer of garment in West Java. Review of European Studies, 7(7), 69-79. https://doi.org/10.5539/res.v7n7p69 
Mogielnicki., R. (2019). Value-Added Tax in Gulf Arab States: Balancing Domestic, Regional, and International Interests, The Arab Gulf States Institute in Washington. Retrieved 28 December 2019, from https://agsiw.org/value-added-tax-in-gulf-arab-states-balancing-domestic-regional-and international-interests/

Odhiambo, O., \& Odada, J. (2015). Effects of zero rating value added tax on government revenue in Namibia: A partial equilibrium analysis. African Journal of Economic and Management Studies, 6(4), 343-355. https://doi.org/10.1108/AJEMS-04-2013-0035

Ramli, R., Palil, M. R., Hassan, N. S. A., \& Mustapha, A. F. (2015). Compliance costs of goods and services tax (GST) among small and medium enterprises. Jurnal Pengurusan, 45, 39-48. https://doi.org/10.17576/pengurusan-2015-45-04

Shaari, N., Ali, A., \& Ismail, N. (2015). Student's awareness and knowledge on the implementation of Goods and Services Tax (GST) in Malaysia. Procedia Economics and Finance, 31, 269-279. https://doi.org/10.1016/S2212-5671(15)01229-0

Wadhwa, P. (2019). The current state of VAT in the GCC countries. SME10X. Retrieved 14 January 2020, from https://www.sme10x.com/10x-industry/the-current-state-of-vat-in-the-gcc countries

Zanganeh, M., Sheikhi, E, A., \& Abdollahi, A. (2018). Studying and identifying the effective factors on tax evasion by Fuzzy DEMATEL-Method. Journal of Optimization in Industrial Engineering, 11(2), 147-152.

\section{Notes}

Note 1. In accordance with the GCC VAT treaty and Article 10 of the KSA VAT law, certain goods and services will be subject to zero rate or will be exempted from the VAT. This will be determined in the KSA Draft VAT Implementing Regulations (Deloitte, 2017).

Note 2. VAT is applied in more than 160 countries around the world as a reliable source of revenue for state budgets (https://www.vat.gov.sa/en)

\section{Copyrights}

Copyright for this article is retained by the author(s), with first publication rights granted to the journal.

This is an open-access article distributed under the terms and conditions of the Creative Commons Attribution license (http://creativecommons.org/licenses/by/4.0/). 